\title{
IMPACT OF OPTICAL INDICES ON PARTICLE SIZE DISTRIBUTION OF ACTIVATED SLUDGE MEASURED BY LASER DIFFRACTION METHOD
}

\author{
WPLYW PARAMETRÓW OPTYCZNYCH NA ROZKŁAD \\ GRANULOMETRYCZNY OSADU CZYNNEGO WYZNACZONY \\ METODĄ DYFRAKCJI LASEROWEJ
}

\begin{abstract}
The important factors that strongly influence the particle size distributions measured by the laser diffraction method are the optical parameters of the suspension (refractive index and absorption coefficient). Knowledge of the values of these parameters is necessary for Mie theory. Mie theory is applied for conversion of the intensity of light recorded on detectors into particle size distribution (PSD) of tested material. Both wastewater and activated sludge are mixtures of a variety of elements (mineral or organic, including living organisms). In practice, it is not possible to define clearly the values of the optical parameters, as the composition of the suspension changes over time. The aim of the study was to estimate the impact of assumed values of the optical parameters on particle size distributions obtained. The PSDs of suspensions sampled in different stages of wastewater treatment are the most reproducible when the following optical parameters are defined: absorption coefficients -1.0 and the refractive index -1.52 .
\end{abstract}

Keywords: laser diffraction method (LDM), particle size distribution (PSD), wastewater, activated sludge, Mie theory, optical parameters

\section{Introduction}

Research on activated sludge and wastewater in the wastewater treatment process follows multifarious directions. Some researchers attempt at identification of species and numbers of various organisms [1-3] or analysis of the structure of biological communities inhabiting activated sludge and description thereof by means of relevant indices [4-6]. Other investigators focus their research on the prevalence of pathogenic organisms and their dormant forms or eggs in sludge and wastewater [7,8]. Others investigate the relationship between the presence of protozoa in sludge and the structure and morphology of flocs on

\footnotetext{
${ }^{1}$ Institute of Agrophysics, Polish Academy of Sciences, ul. Doświadczalna 4, 20-290 Lublin, Poland, phone +48817445061 , fax +48 817445067

${ }^{2}$ Faculty of Environmental Engineering, Lublin University of Technology, ul. Nadbystrzycka 40B, 20-618 Lublin, Poland, phone +48 8153843 22, email: g.lagod@pollub.pl

*Corresponding author: a.sochan@ipan.lublin.pl
} 
the course of the wastewater treatment process [9-11]. An important and currently commonly discussed tasks in wastewater treatment technology are the ways of description of physiological activity of activated $[12,13]$ and fractioning of the substrate to build and calibrate computer models of sewage treatment systems [14-18]. An important aspect of investigation is also application of raw and treated sewage in agriculture [19-21].

One of the recent research areas, currently at a stage of refinement of the measurement methodology, is the use of laser diffraction to determine particle size distribution of activated sludge flocs and to analyse the course of wastewater treatment processes [22-27]. Other measurement techniques based on analysis of microscopic images or light passing through a measuring system containing activated sludge flocs are also employed in similar investigations [28, 29].

The laser diffraction method is based on measurements of the intensity of laser light scattered on tested particles. The light intensity recorded on detectors is converted (using Fraunhofer and Mie theories) into particle size distribution [30-32]. Currently, the laser diffraction method is widely used in investigations of soil and sludge [33-37].

While using the LDM for analysis of particle size distribution of sludge flocs, one should bear in mind that the result obtained (size distribution) is largely dependent on the investigation procedure applied [25]. Flocs have a delicate structure, which disintegrates into finer structures under the impact of an external force (eg mechanical stirring). The degree of the disintegration will be related to the energy of stirring. In turn, the energy of stirring will depend on the construction of the dispersion unit of the diffractometer (including the design of the stirrer and pump) and on the speed of stirring and pumping [38]. Therefore, the method can be used for comparison of results obtained in different laboratories only when measurements are done using the same device and measurement procedure. Nonetheless the measurements of sewage sludge parameters conducted with LDM can be especially useful when within the single laboratory there is conducted research on influence of the particular technological processes or additive of chemical substances on sewage sludge parameters [27].

This provision concerning the use and interpretation of the results does not eliminate the possibility of using the LDM for analysis of sludge flocs in wastewater treatment process. A great number of investigations are focused on evaluation of the treatment process and the improvement of operating parameters of wastewater treatment plants. One of the measures/parameters for assessment this process is the mechanical stability of activated sludge flocs. Hence, with a standardised measurement procedure (the same device and setting of pump and stirrer speed), distributions obtained with the LDM provide important information about the process itself and mechanical properties of sludge.

The application of the LDM in analysis of wastewater and activated sludge is associated with another methodological difficulty, ie determination of the value of optical coefficients, ie the absorption coefficient and refractive index, which is essential if calculation of the distribution is to be based on Mie theory.

The difficulty in estimation of the values of the optical coefficients results from the diversity of the components of activated sludge, which contains both suspended finefraction mineral or organic particles [39] and various organisms [40, 41]. Since the selection of any values will be controversial and may be a potential source of error, the authors identified as the aim of their work to: i) assess the degree of the impact of different values of the absorption coefficient and refractive index on particle size distributions of 
activated sludge; ii) propose the values of optical parameters for which the uncertainty is the smallest.

\section{Materials and methods}

Suspensions sampled from two points in waste water treatment plant (WWTP) in Lublin (Poland): from the primary settling tank and from the nitrification chamber were used in this experiment. WWTP purifies (approx. 65,000 $\mathrm{m}^{3} /$ day) municipal and industrial wastewaters from Lublin agglomeration.

To obtain the averaged sample, portions of about $0.3 \mathrm{dm}^{3}$ were collected in a $1.5 \mathrm{dm}^{3}$ container. The time between sampling and measurement was about 20 minutes (only for transport from WWTP to the laboratory). The sample was kept in the car fridge at that time. Immediately prior to measurements, the container was vigorously mixed for homogenization and then three subsamples were taken for three repetitions.

Mastersizer 2000 (Malvern, UK) with a Hydro MU dispersion unit was used as the laser diffractometer. The measuring range was from $0.02 \mu \mathrm{m}$ to $2 \mathrm{~mm}$. The following settings were used [25]:

- volume of the measured suspension - about $800 \mathrm{~cm}^{3}$; The raw suspension (without concentration by centrifugation or evaporation; the dilution in distilled water was necessary in some cases to obtain the obscuration in the range 10-20\%) was added to the dispersion unit,

- $\quad$ speed of the stirrer and pump (pump and stirrer are integrated in this dispersion unit) $1500 \mathrm{rpm}$,

- $\quad$ ultrasounds - $35 \mathrm{~W}$ (maximum) for 4 minutes.

Because the Mastersizer 2000 records rough data from the detectors, it facilitates recalculation of the data from the same measurement using different values of optical indices. The PSDs were calculated for the selected combinations of the following values of optical indices:

- $\quad$ absorption coefficient: $0.001,0.01,0.05,0.1,1.0$,

- refractive index: $1.00,1.20,1.52,1.70,2.00$.

Two wavelengths of light were used in the Mastersizer - red $(633 \mathrm{~nm})$ and blue (466 nm). A single measurement lasted one minute - $30 \mathrm{~s}$ (ie 30,000 counts) for the red and $30 \mathrm{~s}$ (ie 30,000 counts) for the blue light. Obscuration during the PSD measurements was established in the range recommended by the producer, ie 10-20\%.

\section{Results and discussion}

The PSDs obtained for the selected combinations of optical indices for two suspensions (mechanically purified wastewater and wastewater with activated sludge) are presented in Figures 1 and 2 .

Figures 1 and 2 shows that the optical parameters exert a stronger impact on the PSD of the suspension from the primary settling tank than that from the nitrification chamber. It can be concluded that there is no influence of the optical parameters on PSD obtained by the LDM at all in the case of the nitrification chamber, because the particles suspended there are comparatively big and Fraunhofer theory can be used without a substantial error. 
The impact of optical parameters on PSD in the primary settling tank is mostly noticeable for the finest particles. This can be expected because Mie theory (and the optical indices are necessary only for this theory) is dedicated to systems with smaller particles. It can be seen that the small values of the absorption coefficient (Fig. 1; AC $=0.001$ and $\mathrm{AC}=0.01)$ at the different values of the refractive indices exerted a similar impact on PSDs as the values of the refractive indices (Fig. 2 ; $\mathrm{RI}=1.00$ and $\mathrm{RI}=1.52$ ) at the different values of absorption coefficients.

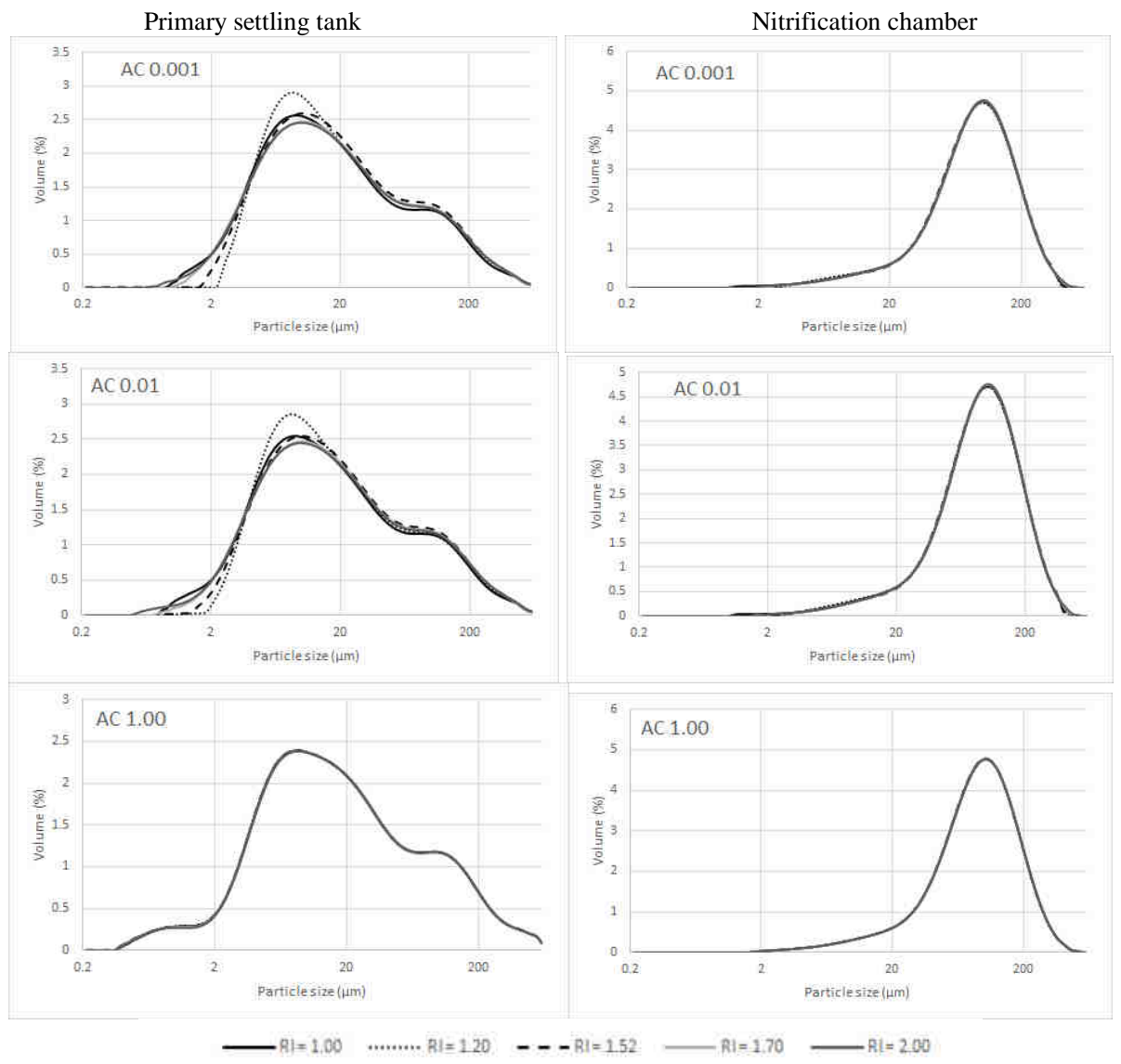

Fig. 1. PSD obtained for different refractive indices (RI) calculated for the assumed absorption coefficients $(\mathrm{AC})$

Since the best reproducibility of PSDs was obtained for the absorption coefficient of 1.0 (irrespective of the refractive index values), this value can be recommended for measurements of suspensions (sewage and activated sludge) in the wastewater treatment process. A question arises - is it the real value of the absorption coefficient for these mixtures? A reliable answer is very difficult because, as mentioned above, the suspension consists of great diversity of mineral or organic particles and life forms. Therefore, one 
needs to define the resultant value - $i e$ an average for the entire sample. The high value of the absorption coefficient seems likely. Yet, the most important argument for adopting it (as a value of 1.00) is the lack of variation in size distributions.

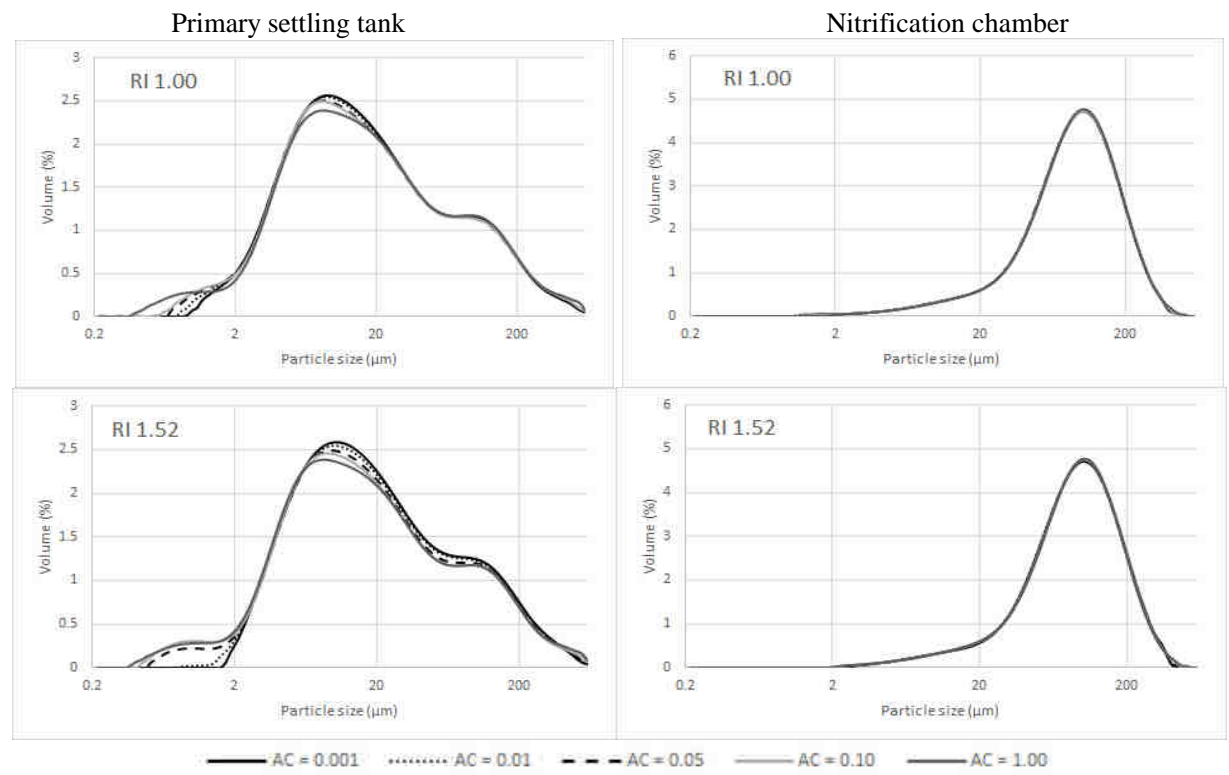

Fig. 2. PSD obtained for different absorption coefficients (AC) calculated for the assumed refractive indices (RI)

Having defined the value of the absorption coefficient, one should define the value of the refractive index. The criterion can be the value of the weighted residual parameter calculated for subsequent distributions. The weighted residual defined by the Mastersizer producer: the residual is an indication of how well the calculated data was fitted to the measurement data. A good fit indicated by a residual of under 1\% [42]. The analysis of the data presented in Table 1 shows that values that were among the smallest ones (with the assumed absorption coefficient value of 1.0) were obtained for the refractive index of 1.52. This value of the refractive index can be recommended for measurements of sewage and activated sludge suspensions.

While comparing the results presented in this paper with the suggestions of other authors, it is worth referring to some other papers. Biggs with Lant [22] examined the size of activated sludge flocs. Given the large variability of the optical parameters of the tested materials, they suggested using Fraunhofer theory, without defining the optical parameters of the sample. A similar approach, ie Fraunhofer theory, was used by Guellil et al [23] and Karczmarek and Gaca [43].

In contrast, Govoreanu et al [44], who discussed the problem of optical parameters for activated sludge flocs, stated that Mie theory should rather be used instead of Fraunhofer theory for activated sludge flocs containing particles smaller than 10 micrometers. They 
followed the idea of Latimer and Wamble [45] and Guan et al [46] that the refractive index of biological solids is very near to that of water $(n<1.05)$.

Table 1

The values of the weighted residual obtained for distributions calculated from the assumed values of optical parameters (absorption coefficient and refractive index) for both suspensions

\begin{tabular}{|c|c|c|c|c|c|}
\hline \multicolumn{3}{|c|}{ Primary settling tank } & \multicolumn{3}{c|}{ Nitrification chamber } \\
\hline $\begin{array}{c}\text { absorption } \\
\text { coefficient }\end{array}$ & $\begin{array}{c}\text { refractive } \\
\text { index }\end{array}$ & $\begin{array}{c}\text { weighted } \\
\text { residual }\end{array}$ & $\begin{array}{c}\text { absorption } \\
\text { coefficient }\end{array}$ & $\begin{array}{c}\text { refractive } \\
\text { index }\end{array}$ & $\begin{array}{c}\text { weighted } \\
\text { residual }\end{array}$ \\
\hline 0.001 & 1.00 & 0.738 & 0.001 & 1.00 & 0.336 \\
\hline 0.001 & 1.20 & 1.115 & 0.001 & 1.20 & 0.479 \\
\hline 0.001 & 1.52 & 0.804 & 0.001 & 1.52 & 0.374 \\
\hline 0.001 & 1.70 & 0.533 & 0.001 & 1.70 & 0.303 \\
\hline 0.001 & 2.00 & 0.408 & 0.001 & 2.00 & 0.286 \\
\hline 0.01 & 1.00 & 0.714 & 0.01 & 1.00 & 0.335 \\
\hline 0.01 & 1.20 & 0.724 & 0.01 & 1.20 & 0.404 \\
\hline 0.01 & 1.52 & 0.566 & 0.01 & 1.52 & 0.337 \\
\hline 0.01 & 1.70 & 0.473 & 0.01 & 1.70 & 0.301 \\
\hline 0.01 & 2.00 & 0.412 & 0.01 & 2.00 & 0.288 \\
\hline 0.05 & 1.00 & 0.724 & 0.05 & 1.00 & 0.330 \\
\hline 0.05 & 1.52 & 0.799 & 0.05 & 1.52 & 0.329 \\
\hline 0.1 & 1.00 & 0.735 & 0.1 & 1.00 & 0.322 \\
\hline 0.1 & 1.52 & 0.888 & 0.1 & 1.52 & 0.317 \\
\hline 1 & 1.00 & 0.389 & 1 & 1.00 & 0.293 \\
\hline 1 & 1.20 & 0.390 & 1 & 1.20 & 0.294 \\
\hline 1 & 1.52 & 0.397 & 1 & 1.52 & 0.279 \\
\hline 1 & 1.70 & 0.403 & 1 & 1.70 & 0.283 \\
\hline 1 & 2.00 & 0.410 & 1 & 2.00 & 0.287 \\
\hline
\end{tabular}

The authors of the present work support the position that it is better to use Mie theory. It is true that by employing Fraunhofer theory one can avoid the problem with estimation of optical parameters. However, according to ISO 13320:2009 [47], Fraunhofer theory can be used only for suspensions that contain particles bigger than $50 \mu \mathrm{m}$. For a suspension with particles smaller than $50 \mu \mathrm{m}$, Mie theory should be applied. The investigated sediments from WWTP surely had smaller particles (Figs. 1 and 2). Nevertheless, as it was stated above, using Mie theory opens the problem of estimation of optical parameters.

Le et al [48] adopted a refractive index value of 1.52 and absorption 0.1 for measurements, after Bieganowski et al [25]. The latter values were adopted from the paper of Ryżak and Bieganowski [30], who investigated soil. However, the compositions of soil and sediments are different, and hence the properties (including optical parameters) can be different. In the light of the results presented in this work (Figs. 1 and 2), it appears that the value of the refractive index of 1.52 is good, but 1.0 is a better value of the absorption coefficient for particles suspended in wastewater and sediment.

\section{Conclusions}

Since sewages and activated sludge are a mixture of many different substances and living organisms (which also consist of various compounds), in practice it is not possible to determine the value of the optical parameters (absorption coefficient and refractive index) which can be used to characterize these mixtures. The criterion for choice of the values of 
the optical parameters may be to minimize the scatter of measurement reproducibility. On the basis of the results presented in this paper, the best values for the absorption coefficient is 1.0 and for the refractive index 1.52. Adoption of other values of the optical parameters affects to a greater extent the results of distributions obtained and thus makes it more difficult to compare the results obtained in different laboratories. It is very important to stress that the dispersion of the sample should be standardized in such measurements.

\section{Acknowledgements}

Preliminary researches were partly supported by the Ministry of Science and Higher Education of Poland, Grant No: 4949/B/T02/2008/34.

The work was presented at International Scientific and Technical Conference Water Treatment Technologies - Technical, Biological and Ecological Aspects, Kyiv 3-5 December 2013.

\section{References}

[1] Lee S, Basu S, Tyler CW, Wei IW. Ciliate populations as bio-indicators at Deer Island treatment plant. Advances Environ Res. 2004;8(2-4):371-378. DOI: 10.1016/S1093-0191(02)00118-1.

[2] Puigagut J, Salvado H, Garcia J. Short-term harmful effects of ammonia nitrogen on activated sludge microfauna. Water Res. 2005;39(18):4397-4404. DOI: 10.1016/j.watres.2005.08.008.

[3] Pérez-Uz B, Arregui L, Calvo P, Salvadó H, Fernández N, Rodrígeuz E, et al. Assessment of plausible bioindicators for plant performance in advanced wastewater treatment systems. Water Res. 2010;44(17):5059-5069. DOI: 10.1016/j.watres.2010.07.024.

[4] Jiang JG, Shen YF. Use of the aquatic protozoa to formulate a community biotic index for an urban water system. Sci Total Environ. 2005;346(1-3):99-111. DOI: 10.1016/j.scitotenv.2004.12.001.

[5] Madoni P. A sludge biotic index (SBI) for the evaluation of the biological performance of activated-sludge plants based on the microfauna analysis. Water Res. 1994;28(1):67-75. DOI: 10.1016/00431354(94)90120-1.

[6] Łagód G, Chomczyńska M, Montusiewicz A, Malicki J, Bieganowski A. Proposal of measurement and visualization methods for dominance structures in the saprobe communities. Ecol Chem Eng S. 2009;16(3):369-377.

[7] Malicki J, Montusiewicz A, Bieganowski A. Improvement of counting helminth eggs with internal standard. Water Res. 2001:35(9):2333-2335. DOI: 10.1016/S0043-1354(00)00517-0.

[8] Bożek U, Kłapeć T. Correlation between biological agents and levels of heavy metals in municipal sewage sludge. Ann Agricult Environ Med. 2008;15(2):295-299.

[9] Arregui L, Serrano S, Linares M, Pérez-Uz B, Guinea A. Ciliate contributions to bioaggeregation: laboratory assays with axenic cultures of Tetrahymena thermophila. Internat Microbiol. 2007;10(2):91-96.

[10] Arregui L, Linares M, Pérez-Uz B, Guinea A, Serrano S. Involvement of crawling and attached ciliates in the aggregation of particles in wasterwater treatment plants. Air Soil Water Res. 2008;1:13-19.

[11] Pajdak-Stós A, Fiałkowska E, Fyda J, Babko R. Resistance of nitrifiers inhabiting activated sludge to ciliate grazing. Water Sci Technol. 2010;61(3):573-580. DOI: 10.2166/wst.2010.868.

[12] Spanjers H, Vanrolleghem P. Respirometry as a tool for rapid characterization of wastewater and activated sludge. Water Sci Technol. 1995;31(2):105-114.

[13] Lagarde F, Tusseau-Vuillemin M, Lessard P, Heduit A, Dutrop F, Mouchel JM. Variability estimation of urban wastewater biodegradable fractions by respirometry. Water Res. 2005;39(19):4768-4778. DOI: 10.1016/j.watres.2005.08.026.

[14] Vollertsen J, Hvitved-Jacobsen T. Biodegradability of wastewater - a method for COD-fractionation. Water Sci Technol. 2002;45(3):25-34.

[15] Mąkinia J, Rosenwinkel KH, Spering V. Long term simulation of the activated sludge process at the Hanover-Gruemmerward pilot WWTP. Water Res. 2005;39(8):1489-1502. DOI: 10.1016/j.watres.2005.01.023.

[16] Dulekgurgen E, Dogruel S, Karahan O, Orhon D. Size distribution of wastewater COD fractions as an index for biodegradability. Water Res. 2006;40(2):273-282. DOI: 10.1016/j.watres.2005.10.032. 
[17] Pasztor I, Thury P, Pulai J. Chemical oxygen demand fractions of municipal wastewater for modeling of wastewater treatment. Internat J Environ Sci Technol. 2009;6(1):51-56.

[18] Drewnowski J, Makinia J. Modeling hydrolysis of slowly biodegradable organic compounds in biological nutrient removal activated sludge systems. Water Sci Technol. 2013;67(9):2067-2074. DOI: 10.2166/wst.2013.092.

[19] Nosalewicz M, Stępniewska Z, Nosalewicz A. Effect of soil moisture and temperature on $\mathrm{N}_{2} \mathrm{O}$ and $\mathrm{CO}_{2}$ concentrations in soil irrigated with purified wastewater. Internat Agrophys. 2013;27(3):299-304. DOI: 10.2478/v10247-012-0098-3.

[20] Qiu L, Zhu J, Zhu Y, Hong Y, Wang K,. Deng J. Land use changes induced soil organic carbon variations in agricultural soils of Fuyang County, China. J Soil Sediment. 2013;13(6):981-988. DOI: 10.1007/s11368-013-0684-4.

[21] Rojas R, Morillo J, Usero J, Delgado-Moreno L, Gan J. Enhancing soil sorption capacity of an agricultural soil by addition of three different organic wastes. Sci Total Environ. 2013;458:614-623. DOI: 10.1016/j.scitotenv.2013.04.032.

[22] Biggs CA, Lant PA. Activated sludge flocculation: on-line determination of floc size and the effect of shear. Water Res. 2000;34(9):2542-2550. DOI: 10.1016/S0043-1354(99)00431-5.

[23] Guellil A, Thomas F, Block JC, Bersillon JL, Ginestet P. Transfer of organic matter between wastewater and activated sludge flocs. Water Res. 2001;35(1):143-150. DOI: 10.1016/S0043-1354(00)00240-2.

[24] Nopens I, Biggs CA, De Clerq B, Govoreanu R, Wilen BM, Lant P, et al. Modeling the activated sludge flocculation process combining laser light diffraction particle sizing and population balance modelling (PBM). Water Sci Technol. 2002;45(6):41-49.

[25] Bieganowski A, Łagód G, Ryżak M, Montusiewicz A, Chomczyńska M, Sochan A. Measurement of activated sludge particle diameters using laser diffraction method. Ecol Chem Eng S. 2012;19(4):597-608. DOI: $10.2478 / \mathrm{v} 10216-011-0042-7$.

[26] Tuszyńska A, Kołecka K. Particle size analysis of suspensions in removing of organic matter and phosphorus from wastewater and surface water. Architect Civil Eng Environ. 2012;4:113-119.

[27] Dereszewska A, Tuszyńska A, Cytawa S. Application of the laser diffraction particle size analyzer to the study of the changes of activated sludge structure in the presence of surfactant. Proc ECOpole. In print.

[28] Chung HY, Lee DJ. Porosity and interior structure of flocculated activated sludge floc. J Colloid Interface Sci. 2003;267(1):136-143. DOI: 10.1016/S0021-9797(03)00682-9.

[29] Chu CP, Lee DJ. Structural analysis of sludge flocs. Advan Powder Technol. 2004;15(5):515-532. DOI: $10.1163 / 1568552042000246$.

[30] Ryżak M, Bieganowski A. Methodological aspects of determining soil particle-size distribution using the laser-diffraction method. J Plant Nutr Soil Sci. 2011;174(4):624-633. DOI: 10.1002/jpln.201000255.

[31] Kovalenko CG, Babuin D. Inherent factors limiting the use of laser diffraction for determining particle size distributions of soil and related samples. Geoderma. 2013;193:22-28. DOI: 10.1016/j.geoderma.2012.09.006.

[32] Wang WP, Liu JL, Zhang JB, Li XP, Cheng YN, Xin WW, et al. Evaluation of laser diffraction analysis of particle size distribution of typical soils in China and comparison with the Sieve-Pipette method. Soil Sci. 2013;178(4):194-204. DOI: 10.1097/SS.0b013e31829908be.

[33] Ismail SB, de La Parra CJ, Temmink H, van Lier JB. Extracellular polymeric substances (EPS) in upflow anaerobic sludge blanket (UASB) reactors operated under high salinity conditions. Water Res. 2010;44(6):1909-1917. DOI: 10.1016/j.watres.2009.11.039.

[34] Karhu M, Kuokkanen V, Kuokkanen T, Rämö J. Bench scale electrocoagulation studies of bio oil-in-water and synthetic oil-in-water emulsions. Sep Purif Technol. 2012;96:296-305. DOI: 10.1016/j.seppur.2012.06.003.

[35] Wojcieszczuk T, Hammal O, Malinowski R, Wojcieszczuk M, Chorągwicki Ł. The activity of chemical components of light and heavy soil in Syria after use of municipal sewage sludge from Deir Ezzor City (in Polish). Soil Sci Ann. 2012;63(3):43-48.

[36] Walkiewicz A, Bulak P, Brzezińska M, Włodarczyk T, Polakowski C. Kinetics of methane oxidation in selected mineral soils. Internat Agrophys. 2012;26(4):401-406. DOI: 10.2478/v10247-012-0056-0.

[37] Nosalewicz A, Lipiec J. The effect of compacted soil layers on vertical root distribution and water uptake by wheat. Plant Soil. 2014;375:229-240. DOI:10.1007/s11104-013-1961-0.

[38] Sochan A, Bieganowski A, Ryżak M, Dobrowolski R, Bartmiński P. Comparison of soil texture determined by two dispersion units of Mastersizer 2000. Int Agrophys. 2012;26(1):99-102. DOI: 10.2478/v10247-0120015-9.

[39] Eikelboom DH. Process Control of Activated Sludge Plants by Microscopic Investigation. London: IWA Publishing; 2000. 
[40] Martín-Cereceda M, Serrano S, Guinea A. A comparative study of ciliated protozoa communities in activated-sludge plants. FEMS Microbiol Ecol. 1996;21(4):267-276. DOI: 10.1111/j.15746941.1996.tb00123.x.

[41] Pogue AJ, Gilbride KA. Impact of protozoan grazing on nitrification and the ammonia- and nitrite-oxidizing bacterial communities in activated sludge. Can J Microbiol. 2007;53(5):559-571. DOI: 10.1139/W07-027.

[42] Malvern Instruments Ltd., Operators Guide, MAN 0247, Issue 2.0, October 1999, Worcestershire. WR14 1XZ, United Kingdom.

[43] Karczmarek AM, Gaca J. Effect of two-stage thermal disintegration on particle size distribution in sewage sludge. Polish J Chem Technol. 2013;15(3):69-73. DOI: 10.2478/pjct-2013-0047.

[44] Govoreanu R, Saveyn H, Van der Meeren P, Vanrolleghem PA. Simultaneous determination of activated sludge floc size distribution by different techniques. Water Sci Technol. 2004;50(12):39-46.

[45] Latimer P, Wamble F. Light scattering by aggregates of large colloidal particles. Appl Optics. 1982;21(13):2447-2455.

[46] Guan J, Waite TD, Amal R, Bustamante H, Wukasch R. Rapid determination of fractal structure of bacterial assemblages in wastewater treatment: Implications to process optimization. Water Sci Technol. 1998;28(2):9-15. DOI: 10.1016/S0273-1223(98)00426-0.

[47] ISO 13320:2009. Particle size analysis - Laser diffraction methods. International Organization for Standardization. Geneva. Switzerland.

[48] Le NT, Julcour C, Ratsimba B, Delmas H. Improving sewage sludge ultrasonic pretreatment under pressure by changing initial pH. J Environ Manage. 2013;128:548-554. DOI: 10.1016/j.jenvman.2013.06.001.

\title{
WPLYW PARAMETRÓW OPTYCZNYCH NA ROZKŁAD GRANULOMETRYCZNY OSADU CZYNNEGO WYZNACZONY METODĄ DYFRAKCJI LASEROWEJ
}

\author{
${ }^{1}$ Instytut Agrofizyki im. Bohdana Dobrzańskiego Polskiej Akademii Nauk, Lublin \\ ${ }^{2}$ Wydział Inżynierii Środowiska, Politechnika Lubelska
}

\begin{abstract}
Abstrakt: Czynnikami, które w istotny sposób wpływają na rozkłady granulometryczne wyznaczane za pomocą dyfrakcji laserowej, są parametry optyczne mierzonej zawiesiny (współczynnik załamania światła oraz współczynnik absorpcji). Znajomość wartości tych parametrów jest niezbędna przy zastosowaniu teorii Mie. Teoria Mie jest wykorzystywana do przeliczenia intensywności światła zmierzonego na detektorach na rozkład granulometryczny (PSD) badanego materiału. Zarówno ścieki, jak i osad czynny są mieszaninami bardzo różnych składników (mineralnych i organicznych, w tym żywych organizmów). W praktyce nie ma możliwości określenia rzeczywistych wartości parametrów optycznych mieszanin, tym bardziej, że ich skład zmienia się w czasie. Celem niniejszej pracy było określenie wpływu założonych wartości parametrów optycznych na uzyskiwane rozkłady granulometryczne. Rozkłady granulometryczne zawiesin pobranych na różnych etapach oczyszczania ścieków są najbardziej powtarzalne dla następujących wartości współczynników optycznych: współczynnika absorpcji - 1,0 i współczynnika załamania światła - 1,52.
\end{abstract}

Słowa kluczowe: metoda dyfrakcji laserowej, rozkład granulometryczny, ścieki, osad czynny, teoria Mie, parametry optyczne 